\title{
The Conditions for after Work: Financialization and Informalization in Posttransition South Africa
}

\author{
ANNE-MARIA MAKHULU
}

ANNE-MARIA MAKHULU, assistant professor of cultural anthropology and African and African American studies at Duke University, is a coeditor of Hard Work, Hard Times: Global Volatility and African Subjectivities (U of California P, 2010). Her book manuscript "The Geography of Freedom: Cape Town in Transition" is under review. Other current projects include work on finance.
N A TIME OF FINANCIAL CRISIS, THE AMOUNT OF TALK ABOUT THE NAture and challenges of employment-what Kathi Weeks aptly describes as "the problem with work" in her eponymous book (2011) - should hardly be surprising. While work is in short supply in some parts of the world, in others employment has intensified and necessarily become increasingly exploitative; in still other places work, in the sense of formal wage employment, has rarely if ever been a given. ${ }^{1}$ Addressing these structural transformations in the global labor market, theorists have tried to develop a new vocabulary to describe the precariousness of work: the emergence of a class of workers made up of those destined to remain poor because of underemployment or depressed wages and those subject to intermittent and even permanent unemployment. This new "contingent class," though perhaps analogous to Karl Marx's lumpen proletariat (Eighteenth Brumaire), has arisen from different conditions.

In many postindustrial economies, irregular and poorly paid service jobs define the experience of the contingent class. ${ }^{2}$ Confined to unsustainable and unsustaining employment, many workers rely, if only intermittently, on the welfare system. Yet assistance, such as it is, involves punitive surveillance that distinguishes between eligible beneficiaries and those who must be sanctioned for failure to live up to so-called individual responsibility (Prashad 157). Welfare "reform" has redirected bureaucratic energies toward removing people from welfare or forcing them into "workfare" (Handler), while paradoxically enforcing the "centrality of wage labor in the social order" (Barchiesi 10), despite the waning of wage work as we know it. The already vulnerable, particularly women and members of minorities, are most likely to be overrepresented in the ranks of the contingent

(C) 2012 BY THE MODERN LANGUAGE ASSOCIATION OF AMERICA 
class, so immediately do they feel the impact of shifts in the labor market, including the outsourcing and offshoring of manufacturing jobs and financial and technological innovations that have created redundancies in domestic markets. Guy Standing has argued that the new horizon of work offers little beyond insecure employment-jobs with few protections and of limited duration-and insufficient state and corporate entitlements (24). It seems that the postwar Keynesian compact has been broken in many parts of the postindustrial north. But what of postcolonial nations to the south? There assumptions about work and welfare are surely different.

My essay focuses on the career of work in South Africa during the period leading up to and immediately following the transition from apartheid to democracy in the early 1990s, a period marked by South Africa's "reintegration" into the global marketplace after the lifting of sanctions and the reversal of corporate divestments that began in the 1980s-even though South Africa was never really disconnected from global capital flows and circuits of exchange. I locate my discussion in emerging paradigms advocating a "theory from the South" that use South Africa as an ideal laboratory for examining relations of growing inequality and the precarious conditions of work as these play out in the peculiarly financialized structure of the South African economy. ${ }^{3}$ While mainstream critics of neoliberalism often see the volatility of work as a consequence of financialization, I will try to show the ways in which precarious and uneven conditions of the wage relation may historically precede or serve as the precondition for financialization and the moral hazards that follow. Further, as a result of a long history of informalization (one expression of the precariousness of work), the persistence of the informal sector under the new regime begins not only to blur the divide between life and work, or employability and disposability, but also to establish a history before the wage.
Let me begin by offering a sense of labor in production in the late 1940s - the period after World War II when South Africa experienced an economic boom much as metropolitan economies did. Here, on the ostensible periphery of the world system, mining was a key index of South Africa's modernity. In Mine Boy (1946), Peter Abrahams's quintessential workerist novel, we see the figure of the black miner depicted in terms of his alienation, resulting from the stripping of the means of production, and in terms of his freeing, in the ironic sense that Marx noted as the primary experience of the moment of original or "primitive accumulation" (Process of Production 873-940). The protagonist, Xuma, is a young migrant from the rural areas headed to Johannesburg in search of work. Through his friendship with an Irish foreman called Paddy, he grows steadily conscious of the racial-political economy of 1940s South Africa. The racial and ethnic hierarchy of the mining compounds with its minutely specified division of labor-Zulus, Shangaans, Sothos all assigned to different tasks under the watchful and authoritarian eye of the white boss-is well known (Donham). Yet the work is so brutal that the account of Xuma's first day on the job causes readers both recognition and abreaction:

For Xuma the day was strange. Stranger than any day he had ever known. There was the rumbling noise and the shouting and the explosions and the tremblings of the earth. And always the shouting indunas driving the men on to work. And over all those was the bitter eyes and hardness of the white man who had told him to push the truck when he did not know how.

Abrahams goes on to underline the futility of the task as Xuma is assigned to build what are known in South Africa as "headgears"the dumps that rise out of the earth as silt is brought up from underground and discarded after the tiny amounts of ore it contains have 
been extracted. The heavy physical labor Xuma is assigned seems to lack a purpose, as if he were digging a hole and then filling it. The sense of purposelessness speaks volumes of the discontinuity between opposing ends of the commodity chain: the production and consumption ends, the hard labor of mining and the uses to which gold is put, often as frivolous ornament or store of value in times of financial panic (such as that following the 2008 financial crisis).

The workers' ignorance of where commodities go and the consumers' ignorance of where commodities come from are consistent with the many other sleights of hand essential to commodity fetishism. From Marx, in volume 1 of Capital, to Sidney W. Mintz, in his brilliant historical anthropology of sugar, Sweetness and Power (1985), critics have long noted the necessary obfuscation of relations between producers and consumers and the violence that is integral to those relations (Taussig). The brutality of the production process is explicit in Mine Boy. Abrahams is well known to have converted to Marxism in the late 1930s in part as a response to the disillusionment he felt about liberal humanism. Yet, as Jean-Philippe Wade has argued compellingly, Abrahams writes about Xuma and Paddy's friendship in terms that hint at a vestigial liberalism. What goes less remarked in the novel, Wade proposes, is the exploitation of black bodies and more remarked the "superexploitation of these workers due to their $\mathrm{ra}$ cial oppression" (98), which Xuma and Paddy transcend, linking arms to join in struggle against the mine bosses at the end of the novel. But perhaps Wade falls into a trap here, for, as I will argue, the South African left has had difficulty keeping racial and class oppression in tension. And as the neoliberal reforms of the past two decades continue to erode the working-class opportunities that were made possible by jobs in mining, manufacturing, and agriculture, Mine Boy has come to exemplify a kind of work, or labor, on the wane.
I have said little till now of the distinction between work and labor. While this special issue of PMLA is dedicated to the idea of work in its many forms both present and past, I want to treat work as a specifiable experience that need not necessarily imply a relation to abstract labor following Marx. Instead, I want to focus on the historically specific and contingent conditions of work that may or may not reside within capitalism and that, in Dipesh Chakrabarty's words, encompass "intimate and plural relationships to capital, relationships that range from opposition to indifference" and, presumably, to acquiescence (671). The reluctance of indigenous peoples to be incorporated into wage labor on the southern African frontier, beginning in the nineteenth century, reflects the ways in which land and livelihood previously constructed worlds that were more valuable than those of wage labor. This fact, not unique to South Africa, anticipated struggles to proletarianize the peasantry that were steadily allayed through land dispossession and most directly through the Natives Land Act (no. 27 of 1913), which divested Africans of rights in land ownership and set aside a system of segregated reserves (Feinberg). Criminalizing land transfers to blacks from whites left approximately eighty percent of land in white hands. For all intents and purposes the means of production were alienated. The domain of work, in the strict sense of activities operating beyond the realm of the capitalist labor market, inevitably shrank as wage labor became the dominant mode of productive activity.

This dramatic shift in land ownership drives the opening pages of Alan Paton's novel Cry, the Beloved Country. Published in 1948, the year the National Party came to power and inaugurated apartheid, the novel opens with a poignant description of Ixopo, in rural Zululand: "There is a lovely road that runs from Ixopo into the hills. These hills are grass-covered and rolling, and they are lovely beyond any singing of it. The road climbs 
seven miles into them, to Carisbrooke; and from there, if there is no mist, you look down on one of the fairest valleys of Africa" (33). A little farther down from this land, owned by affluent white farmers, is a stark break in the landscape: "Where you stand the grass is rich and matted, you cannot see the soil. But the rich green hills break down. They fall to the valley below, and falling, change their nature. For they grow red and bare; they cannot hold the rain and mist, and the streams are dry in the kloofs. Too many cattle feed upon the grass, and too many fires have burned it" (33-34). Cry, the Beloved Country ultimately belongs to the liberal humanist tradition that calls for reform rather than for the revolution Abrahams advocates. Yet African migrants' search for work in the city is the premise of each novel because work is no longer sustaining or sustainable and rural South Africa has become denuded of its fertile land and of its people, who have been forced to leave it.

Abrahams's and Paton's novels depict a world of factory and mining work that entices Africans from the countryside into the big city. Both are Fordist-inspired, though Fordism seems out of place as a term describing the hybrid forms of work that drove South Africa's industrial economy, in part because at no time was work exclusively the domain of capitalist production or a domain outside it. The ambiguity of work's relation to capitalist production in South Africa complicates the northern narrative of a discernible break between Fordism and post-Fordism at the dawn of the postapartheid era, and it challenges a generalized nostalgia for the era of work so prominent in the recent literature of the Euro-American left. ${ }^{4}$ Hence neither Fordism nor post-Fordism quite applies to the current work crisis in South Africa-the changes in the labor market taking place at the southernmost tip of Africa, the notions of loss of work that are complicated by the primacy of wage work under apartheid and the absence of work under constitutional democracy.
By contrast, the recent theorizing of precarity and precariousness and of the purported emergence of a "precariat" class takes for granted that industrial wage work is the background against which flexibilization and dematerialization of the labor market have occurred (Standing; Prashad; Butler). Standing draws most of his comparisons from northern Europe, the United States, and Japan, where the casualization of wage work resulting from the reduction of the work week and the outsourcing of office functions to China and India has led to the underemployment of a former working class already afflicted by the demise of welfare benefits (see also Prashad). To speak of a precariat as a "class-in-the-making," as Standing does (7), presumes something about what came before that has little basis in colonial labor markets. By contrast, Jane Guyer's meticulous attention to the longue durée experience of Atlantic Africans in economies stretching the length of the West African coastal region frames an array of activities - profit making, getting by, and wagering - that have long been the domain of African work practices. The "expectation of gain" has organized monetary transactions; it has also been a "persistent motive behind the macrohistory of European monetary engagement in Africa" and of work itself (17). Yet, as distinct from the triad of jobs, citizenship, and welfare-common to certain northern democracies-work in the mode Guyer describes assumes always and before the fact a condition of precariousness.

By addressing the term work historically and analytically, I intend to offer some insight into contemporary debates about the crisis of unemployment. In South Africa, the absence of formal wage work and the predominance of conditions of superfluity have expanded what I will call the "informal sector." This sector is neither a residual category nor the domain of marginal economic activities but rather a site of economic life that is often 
highly organized, central to the livelihood of vast numbers of people, and ought, therefore, to preoccupy economic theory (Roitman, Fiscal Disobedience). In times of extreme need, ${ }^{5}$ the informal sector creates continuity between the state and global markets through a repertoire of practices and forms of life. ${ }^{6}$ Further, "[i]nformal and contingent occupations have absorbed many of the unemployed created by the restructuring of formal enterprises" (Barchiesi 6), effectively compromising the political investments in wage work that depict jobs as powerful symbols of democratic citizenship in postapartheid South Africa. The classic figure of the wage laborer persists, but the solidity of the conditions that sustained it does not. As a number of cultural theorists-most notably, Sarah Nuttall-have observed, the cultural representation of the ideal worker has come to be mediated by the conditions of a service economy and practices of consumption in which, say, miners' protective gear reappears as fashion garments and objects of consumer desire.

In the nineteenth century, with the advent of South Africa's industrial revolution (following the discovery of gold and diamonds) and the subsequent proletarianization of the black peasantry through enclosurethe desperate transition from working for oneself to working for others ${ }^{7}-$ Africans were steadily integrated into a system of migrancy that by the mid-twentieth century was well established and that stipulated the presence of temporary labor in the cities and a reserve army of labor in the countryside. This story is all too familiar; it is, after all, the narrative backbone of the apartheid economy as much as the legislative framework of white supremacy - with its techniques of racial, class, and gender oppression-and equally the grounds for political struggle against controlled urbanization, discrimination, and dispossession, a struggle that officially concluded with South Africa's democratization in 1994. Yet even in the 1970s Africanist labor studies were beginning to respond to a growing postindependence disillusionment with the failures of liberation movements, unraveling the classic tale of African proletarianization (Freund; Cooper, Decolonization). Evidently, Africans had not become a revolutionary proletariat even in circumstances that fully incorporated them into wage labor. Their refusal to work; their questioning of the universal, empty time of capital; and their counterposing of alternative cultural forms, values, and modes of productivity all hinted at the possibility of a more thoroughly contingent history of work. Since South Africa gained its independence much later than other African nations, it occupies a different place in Africanist labor studies. Yet resistance to wage employment-to the exploitative conditions of the wage relationwas just as pertinent in South Africa, where high turnover in the workplace, at least in the decades just before 1948, spoke of a politics of resistance to work. Informality, selfemployment, and multiple intermittent jobs offered to a broad range of working people, including unskilled Afrikaner proletarians (Van Onselen), alternatives to the relentless regularity of the mines and the factories. As South Africa industrialized, young residents of African urban townships refused factory work, forcing the state to expand the recruitment of migrant workers (Posel, "Influx Control"), whose unionization eventually fueled labor conflicts (Barchiesi 20).

Beginning in the 1960s, work became conceptually important to neo-Marxist analysis-in particular, to theories of the superexploitation of black labor, the result of "an ongoing history of extremely biased accumulation, combining capitalism and noncapitalist sites of work, of life and of nature" (Bond, "Half-Century" 5). ${ }^{8}$ While the state necessarily used plainly racist methods to dispossess blacks and compel them into the capitalist workforce, racism persisted long after the induction of Africans into wage labor, so that one of the difficulties facing those 
trying to explain South Africa's political economy was the role racial tyranny played in advancing the interests of a capitalist class. In this sense, class and race (and, for that matter, gender) had to be seen as interrelated domains of domination. By focusing on racial rather than class oppression in Mine Boy, Wade may have fallen into the trap of choosing between two modes of oppression rather than keeping them in tension.

Neo-Marxism lacked nuanced analysis of gender and reproduction, echoing many of the 1970s Euro-American Marxist-feminist debates over the right to basic income and reflecting the dualistic thinking behind the notion of productive and reproductive spheres. "Reproductive work in these [debates] usually included the forms of unwaged work through which individuals met their daily needs for food, shelter, and care and raised a new generation to take their place" (Weeks 28). This sphere was understood to stand apart from the productive space of wage labor. Similarly, Prashad's recent analysis of "workfare" (or antiwelfare reform) in the United States highlights the ways in which conservative and neoliberal policies distinguish between affective and productive work even as "[i]mpoverished women stretch their bodies to provide their own services" across both domains (152).

While the inadequacies, or absence, of gender theory to explain the reserves persisted, the Bantustans and their relationship with "metropolitan" South Africa was already being accounted for in terms of uneven development. This concept of uneven and combined development and the articulation of distinct modes (capitalist and noncapitalist) of production thinking were borrowed from Latin American dependency theory, and they effectively connected the poverty of the Bantustans to the process of accumulation in the Republic of South Africa. As a strategic (and theoretical) essentialism, the idea of uneven development relied on a view of the countryside as subject to the impositions of apartheid capitalism and thus limited to supplying a steady stream of labor.

Despite this, South Africans who recall the era of migrant-dependent wage work are nostalgic for its certainties notwithstanding the abuses of a system that critics at the time referred to as "racial Fordism"- the racism of the shop floor, the extreme forms of exploitation, and the forced mobility of migrant workers (Gelb). For reasons different from those organizing the nostalgia for work in the United States or Europe, South African longings for the age of work depend on a careful misrecognition of the historical continuity between work and worklessness. For one thing, the turn to informal economic activity represents a "re-turn" to informality, part of a longer history of informalization resulting from the highly exploitative conditions of wage work that Frederick Cooper has argued lay the groundwork for the underemployment of an African workforce caused by desertions and slowdowns (Confronting 134). For another, the historical sequence of work and the absence of work, as Michael Denning has recently argued, must be troubled, because the presumed continuity between the time of work, in the past, and the time of joblessness, in the present, obscures a much longer history of "wageless life." The "fetishism of the wage," Denning maintains, also delimits the analytic possibilities for theorizing other forms of "practical activity" (80).

The challenge of work across South Africa's democratic transition is not then simply a technocratic consideration, which might be solved by dedicating energies to the promotion of job growth; it is a historical and analytic one as well. Under apartheid, the privileged status of Africans granted permissions to remain permanently in the cities (Section 10 status under the Urban Areas Act) articulated the right to reside in urban areas, coupled with work opportunities, as a partial right of citizenship, if a highly contested and promissory one (Comaroff). ${ }^{9}$ After all, 
the Bantustans were not only sites of reserve labor-passive and superfluous ${ }^{10}$ - but also ethnic homelands given over to the absurdist fantasy of alternative citizenship beyond the boundaries of the republic.

Since South Africa has followed a course like and unlike that of other industrial societies, how it fits into a more expansive world account of the rise of precarious work, informalization, and modes of bare life has to be reckoned in similar and different fashions. The 1994 transition was marked by the (re)emergence of the "worker-citizen," a trope both consistent with South Africa's past history of work and thoroughly discontinuous with it, inasmuch as citizenship for Africans was always a priori denied-the promised transition from subjecthood to full civility and belonging never fulfilled. After all, the focus on the laboring black body-a body on which labor was imposed by the state and at the same time made utterly disposablecould not fully satisfy the continuity between work and citizenship. By contrast, on the other side of South Africa's political transition the refocusing on wage labor-that is, wage labor under threat from global competition-has become the site of the production of claims about citizenship as well as investments in work and democracy.

That the South African transition unfolded against the backdrop of increasing deregulation is news to no one (Bond, Elite Transition); what is worthy of note, however, is the timing of the transition. The belatedness of South Africa's decolonization preempted the possibility of a more profound acknowledgment of the preconditions for freedom-the responsibility to address the political and material injustices of the past-even as the focus remained squarely on "freeing" the market. Though the adoption of laissez-faire policies seems to have coincided with democratization, neoliberal policies had already been embraced by the late apartheid regime, belying the notion of radical rupture across the transition
(Marais). ${ }^{11}$ Instead of seeking to redistribute wealth in a society shot through with extreme inequality, the new dispensation adopted technocratic methods for creating jobs "as an imagined solution to the postapartheid social question." Wage earners have had to take up the cause of the new society while state safety nets have been designed to serve the "deserving" poor (Barchiesi 64-69). But the opening up of South African markets ultimately undermined early policies, and waged employment has remained precarious, leading to a significant expansion of the informal sector (Hirsch). Practically speaking, then, South Africa's neoliberal turn has been partial inasmuch as the local conditions of neoliberalization-the historical conditions of postapartheid, distinguished from an apparently homogeneous process of global neoliberal expansion (Ferguson, Global Shadows) - have dictated the need for an apparatus of social assistance to compensate for jobless growth (Ferguson, "Formalities"). The trajectory of political economy in South Africa has turned back on itself, so that "at the point [political-economic] theory may have been most useful to those engaged in everyday struggle against capitalism during the rise of neoliberalism, it evaporated" (Bond, "Half-Century" 13).

While net job creation occurred early in the first decade of the twenty-first century in heavy industries such as chemicals, minerals, and the automotive sector, just as significant was the expanding number of low-paying, lowskill service-industry jobs ranging from retail to domestic to personal-care work, primarily because of the consumer demands of a new black entrepreneurial class. In many households, social assistance, in the form of pensions and social grants, came to substitute almost entirely for the wage in the face of high levels of unemployment concentrated in mostly poor black urban and rural communities. ${ }^{12}$

The South African transformation from industrial to postindustrial work, which in- 
volves a refocusing on service jobs, is seen in many parts of the world and is roughly understood as post-Fordism (Harvey, Condition). South Africa's place in this larger story is that of a local moment in the history of a world problem. Yet there is much to be learned from an apparently peripheral outpost of the world system.

That South Africans are nostalgic for the age of wage work, that they assume such work to be industrial proletarian-even if tainted by the relations of apartheid that the extreme disciplining of labor makes violently distortive (Harvey, Enigma) - has several implications. I have argued elsewhere that a "desire for sweat" as the basis of material security harks back to a putative golden age of migrant work that was attended and complicated by the fact of state repression (Makhulu, "Search" 29). For a generation of older black South Africans, many now supporting children and grandchildren on small state pensions, the hostilities of the factory floor, mining compounds, and live-in domestic arrangements represent a period of material, if limited political, certainty. Their nostalgia comes at a time of deepening crisis in South Africa, when economic growth has been sanctioned at the expense of job growth (despite all the rhetoric to the contrary). The South African crisis follows a pattern of financialization and speculation leading to job shedding not only at the southernmost tip of the African continent but also across the region and the world and, most recently, giving rise to the global Occupy Movement, which began on Wall Street but whose origins can be traced back to the earlier Spanish encampments and the Arab Spring uprisings. While there may be occasion to wonder about South Africa's capacity to make legible larger worldhistorical forces, particularly given its status as a postcolony, world events suggest that South Africa is as likely an entry point as any into a discussion of significant shifts in the relations of work and its associated forms of life.
Achille Mbembe and Nuttall have called for a comparative and cosmopolitan reading that sees the world as written from Africa, while Jean and John Comaroff have gestured toward the mutual entailments and conjoined hemispheric economies that make it impossible to disarticulate north and south. I too wish to add my claim to a theory from the south and to suggest that the South African contemporary could help us understand recent, fundamental, and far-reaching changes in finance capital and the modes of its representation as much as the forms of work that have emerged almost everywhere as a consequence.

All those who cut their teeth in African studies during the last several decades are painfully aware of the practical consequences of structural adjustment-the losses of jobs, welfare, and productive capacities that were synonymous with the early postindependence era in any number of African countries (Apter; Bayart; Moore and Sanders). South Africa came late to adjustment, and when it did it opted for self-adjustment by repaying apartheid-era debt and freeing its markets. What Benjamin Lee and Edward LiPuma call South Africa's "culture of circulation," set in motion even before the transition, steadily accelerated as the mechanisms for generating value were transformed and the focus on the actual system of exchange redoubled with the attrition of domains of economic and productive life focused on material productionmining, manufacturing, and agriculture. This is hardly a uniquely South African story, though the particularities of the deterritorialization of work and the steady shift to immaterial labor pose especially vexing problems in the context of postapartheid South Africa.

South Africa's economy is dominated by a financial sector making up - or "appropriating"13-approximately twenty percent of the gross domestic product (GDP), while employing a mere one percent of the labor force, in a country with an unemployment 
rate conservatively estimated at twenty-four percent. ${ }^{14}$ It is one thing to speak of gross inequality, another to consider financialization as the form in which inequality should express itself-as a "symptom" of relations of labor exploitation and lived disparities of wealth and poverty (Žižek).

The domain of finance-of listing agencies, investment banks, and private-equity firms-appears uninvolved in or beyond the purview of the exploitative relations of the wage as this has been conventionally understood, certainly in South Africa, where labor bosses have odious reputations and regimes of work were traditionally predicated on the use and abuse of poorly paid semiskilled and unskilled labor. This domain's detachment from wage relations is precisely in the nature of interest-bearing capital, as Marx long ago pointed out. For while initially rooted in the credit system, money capital must eventually be paid off as "real" capital (Marx, Process of Capitalist Production). The sphere of speculation suggests, however, a realm of work at least on initial scrutiny set apart from the old racisms of the shop floor and the disputes caused by racial antagonism-a point Phil Bonner has identified with high labor turnover, especially in the early to mid twentieth century (118). In other words, financialization has tended to obscure, even disavow, ongoing relations of exploitation rooted in a longer history of colonial domination.

I borrow from Gilles Deleuze and Félix Guattari in proposing that the appropriation of one-fifth of GDP by financial services is a mode of capture. ${ }^{15}$ The concept of capture can be linked to the intensive (as opposed to extensive) nature of the current economy, which is focused on technology and speculation rather than forms of accumulation that rely on imperial projects of territorial expansion. Capture also addresses problems associated with the dissolution of wage work and provides ways for theories of postindustrialization to account for value transformations beyond the domain of wage work, as older theories of value that relied on the historical specificities of the factory and commodity production lose relevance. The postapartheid period has seen all the modernist templates for a national liberal-democratic dispensation diffracted, if not exactly shattered (Comaroff and Comaroff, "Reflections"), through profound social changes based in economic shifts that gathered steam in the 1970 s and 1980s as apartheid entered its final phase. The most important among these is the steady withdrawal of capital from fixed, large-scale, labor-intensive production, resulting in high rates of unemployment. This is transforming the nature of change itself in a society where industrialization was long held to be the motor of historical development (White 399). That said, the relation of post-Fordism to the South African present is complicated. Although postFordism refers to a past that enables some understanding of the present, Fordism and its afterlife signify something different in the south, where the industrial democracies that characterized Fordism-mass production and consumption coupled to higher wages and higher productivity (White; Gramsci) - never really existed, since South Africa "was a colonial society where profit came from coercive exploitation of cheap, unskilled labor" (White 399-400). By contrast, financial markets rely on a radically distinct process of capture of a "surplus" or "extra."16

A surplus operates in two ways: as excess and as something redundant and thus disposable. Most South Africans belong to a vast and ever-expanding informal sector, a sphere of activity that cannot produce value in the strict sense but in which the forms of life and conditions for specific forms of life are sustained and daily renewed. For Keith Hart, the informal sector has a decades-long history and hinges on a detachment from the state, unlike the model in which the "worker-citizen" is the basis of apartheid and the postapartheid political economy. Although the informal sector is the "antithesis of the state-made modern 
economy," it teems with life (145). The concept of this sector, superbly rendered by Hart in a recent book entitled The Human Economy, has had a varied career. From the 1980s on, the structural-adjustment programs that shrank state capacities in the global South encouraged an ethos of free enterprise that could only take on precarious and irregular form (to be distinguished from corporate entrepreneurialism). Inevitably, informalization took the place of the developmental state in the guise of "self-help," while the state, which had been responsible for the welfare of its citizens, turned to debt servicing.

I have explored elsewhere the spatial informalization of South African cities as they came under dual imperatives: to optimize the availability of black labor in urban areas-in the name of apartheid industry-and to regard segregation as a practical and political necessity ("Geography"). The counterpoise between these equally powerful tendencies contributed to the creation of a carefully engineered, if often uneven, system of labor migrancy. Further, such competing forces of labor concentration and racial division established the circumstances under which informal settlements arose and eventually persisted in illegally accommodating the attendant needs of labor in production - that is, a temporary laboring force destined to be dispatched because of old age or ill-health to the so-called homelands. As many have remarked, this calculus of staying put and being on the go-a phenomenology of "flight and inhabitation" (Moten)-depended on the superexploitation of women, on forms of labor that were affective, reproductive, social, and largely immaterial (e.g., Posel, Making; Marks and Rathbone). Together these forms sustained an otherwise unsustainable system of labor migration.

To some degree such modes of immateriality have simply been transposed from the countryside to the city through the breakdown of influx controls, demographic pres- sure (in the 1980s), and the temporariness of the migrant experience, which eventually gave way to a politics of staying put in the city (Makhulu, "Question"). It follows that many of the forms of life that appear new, at least after apartheid-because of the expansion of informal settlements and informal activities, the resort to crime as a productive endeavor, a renewed protest politics, and so on ${ }^{17}$-are consistent with longer quotidian struggles over the means of life that were overshadowed by the more prominent antiapartheid politics.

Zakes Mda's poignant account in Ways of Dying of the time just before the end of apartheid (the "pre post-" moment) was penned in anticipation of the democratic transition, and it offers a way to think about the new politics and new forms of life to which I have alluded. Published in 1991, the novel describes a South Africa on the cusp of political change. ${ }^{18}$ Much like Nadine Gordimer in July's People (1982), the prophetic work written a decade earlier, Mda addresses himself to the historical conjunction Antonio Gramsci called the "interregnum." Set in neither town nor country, Ways of Dying concludes in an unnamed squatter camp on the outskirts of an unnamed city, situating the interregnum in an indeterminate place and time and signaling the broader problem of South Africa's unresolved political situation. The novel's characters have grown accustomed to death, which is rarely the natural culmination of a life lived to its fullest. Mda writes of a society wracked by violence in which sudden and unnatural deaths have become commonplace, even as his use of magic realism portends a future freed from political violence. Toloki and Noria, the novel's central characters, are left to imagine the future; in the closing scenes of the novel, the shacks of the squatter settlement glow "in the light of the moon, as if the[ir] plastic colours [we]re fluorescent." Toloki and Noria acknowledge the dramatic changes already taking place around them: "The smell of burning rubber fills the air. 
But this time it is not mingled with the sickly stench of roasting human flesh. Just pure wholesome rubber" (212). ${ }^{19}$

While the problem of political transformation is foregrounded in Ways of Dying, on closer reading the novel offers insights into the specific problems of late-apartheid work. Toloki is a professional mourner who attends funerals in the townships and informal settlements; his assiduous attention to the grief-stricken arises within a continuous double movement between the mundane, everyday concerns of life and death and the broader, spectacular process of South Africa's transition from apartheid to democracy. For if Toloki goes about his professional work dressed in a threadbare magician's costume, shifting between domains of private and public life, his work is both a mark of the pervasiveness of death and a prefiguring of the shift from tyranny to freedom. In this respect in particular, Ways of Dying has an important utopian dimension while the informal settlement-that in-between, numinous space-seems nothing so much as an echo of Frantz Fanon's zone of "occult instability," in which the new national culture is shaped through the experience of anticolonial struggle (Fanon 227; cf. Bhabha). Yet the novel also alludes to the expanding service economy (formal and informal) and the emergence of modes of precarious and contingent work.

If the shift in patterns of work I have described so far may be best summarized as the movement away from the ideal-typical figures of the miner and migrant worker and toward the service worker employed in the informal economy living precariously on the urban periphery-like Xuma and Toloki-the other marked change in patterns of wage and work, life and livelihood, concerns the stark, everexpanding reality of inequality.

In a description of the television series The Lab, which began airing in 2006, Loren Kruger argues that its focus on Black Eco- nomic Empowerment (BEE), in the context of an investment bank where BEE deals are secured, departs from previous representational forms in addressing contradictions arising from the apartheid and postapartheid regimes: "The critique of contradictions in the post-apartheid political and cultural economy has to operate differently from the emphatic opposition to the state characterized by the anti-apartheid movement" (7677). Indissociable from the new critique is the fact that the rhetoric of financial success sets the characters in The Lab apart from a large underclass that in turn must aspire to and emulate the practices of conspicuous consumption, "as the sign of national prosperity," even if such ways of life remain utterly out of reach (76; cf. Bourgouin). Consider Sisifo Mzobe's recent novel Young Blood (2010) and its protagonist, Sipho, a car mechanic who eventually resorts to car-jacking to satisfy consumer fantasies-the seduction of crime in a world of "wreckage" (Napolitano).

Marx observed long ago that Adam Smith's notion of the unregulated free market could function only by debasing and degrading nature and its relation to human beings:

[T]he law which always holds the relative surplus population or industrial reserve army in equilibrium with the extent and energy of accumulation rivets the worker to capital more firmly than the wedges of Hephaestus held Prometheus to the rock. It makes an accumulation of misery a necessary condition, corresponding to the accumulation of wealth.

(Process of Production 799)

While South Africa has spent the last decade and a half borrowing (through foreign debt and consumer credit), its soaring household debt and bank lending only begin to suggest the disproportionate distribution of wealth. Apart from the forms of insecurity and instability to which gross inequalities give rise, these inequalities also reflect similarly unstable processes of capital accumulation-the 
leaps and bounds, bear and bull cycles of capital markets, their focus on risk as a means to accumulation, and the volatility (or insecurity) such efforts promote. The "culture of circulation," in which money generates more money, as LiPuma and Lee have argued, "exaggerates systemic risk" (104), even as recent historical experience suggests that those who command the system of exchange and hence trade in risk are themselves least at risk (Ho). How do such matters relate to questions of "life" and to emergent forms of life in a place like South Africa?

From the perspective of the so-called informal sector and the millions of South African households that articulate daily needs and survival strategies related to, but located beyond, the formal marketplace, their daily efforts exceed the proposition that these constitute methods of survival or overcoming of bare life. The growth of the informal sector entails a shift from thinking about "abjection" to considerations of the "work on the world" achieved by those engaged in everyday practices of social reproduction (Willis); to ignore the intersection of formal and informal economic life replays, blatantly, the received wisdom of contemporary neoliberal economic logic.

In the 1970s South Africans on the intellectual and political left were already arguing for continuity between opposing poles of the economy (as were their Latin American counterparts). Again, I refer back to the analysis of uneven and combined development in South Africa and the mutual dependency of urban and rural areas-the notion of a dual economy to which Harold Wolpe and others adhered (Wolpe, "Capitalism" and Race; Legassick). The two modes of production in the apartheid state were not two independent spheres, despite the rhetoric of "independent" homelands, which denied their connection. David Harvey may be one of the most recent proponents of an argument for "continuity" (New Imperialism), proposing a relation be- tween accumulation and dispossession that parallels older claims concerning the relation between capitalism and underdevelopment (Frank; Amin; Wallerstein).

The unevenness of development in South Africa compels us to think more critically about the financial character of present-day capitalism: that in certain contexts its effects are always amplified by a preexisting terrain of deeply uneven capitalist relations. James Ferguson has argued that capital's trajectory is both rapid-fire and patchy (Global Shadows). It is presumably wide ranging too-horizontal and vertical in its reach and therefore both extensive and intensive in its effects. Even as financialization comes to be understood (often mistakenly) as the cause, not consequence, of inequality-and volatility is understood as following, rather than motivating, speculation-the effects of its force differ, depending on historically produced situations. And South Africa, like many regions in the south, should be more vulnerable to the rapacious effects of an unbridled finance capitalism. ${ }^{20}$

The politics of service denial-the suspension of electricity and water for nonpayment-is a familiar story, as is service providers' use of prepaid meters, which inevitably shut off vital services to those who cannot afford them (Pithouse; Desai; McDonald; Mitlin and Satterthwaite). While nationwide protests against the corporatization of local state functions stem from conditions of poverty that make it virtually impossible for the poor to pay for services, in official circles the general view is not that market-oriented reforms may be unsuited to the complex postapartheid economic climate but rather that the failure to pay rates is consistent with a "culture of non-payment" dating back to the rent and consumer boycotts of the 1980s. This is an astonishing position given the unemployment rate, that cities like Cape Town have poverty rates as high as thirty percent, and that the Eastern Cape-where most migrant workers enter Cape Town-is the second 
poorest province, with a poverty rate of seventy-seven percent (Bähre 373). This is not to suggest that equally urgent struggles have not taken place elsewhere or that the consequences of an economy driven by speculation are more limited in other places (consider the extent of the Occupy Movement in the United States). But the consequences in South Africa are not only extreme but also consistent with a whole history of dispossession.

The financialization of the South African economy, while seemingly unrelated to water shutoffs and service interruptions or the municipal economics of cleansing (sanitation), configures and restructures South Africa's unemployment picture. Indeed, the very condition of financialization appears to be the point at which specific forms of life convert into a kind of inutility or superfluity. While the notion of a reserve army of labor is nothing new, the apparent dematerialization of so many things - work, through retrenchment; homes, through repossession ${ }^{21}$ - suggests that redundancy is somehow consistent with the creation of value in a new form (to draw here on the symptomatic reading). I am tempted to argue that this dematerialization constitutes a new mode of real subsumption of labor by relations of finance capital, that if capital is gradually transforming the social relations and modes of work until they are thoroughly steeped in the logic of capital at a particular historical moment, the current moment is characterized by processes of desubstantiation through which money, by generating more money in the field of speculation, hollows out older arrangements and relations of work. Perhaps, then, real subsumption consists now in the making of work into nonwork or at the least into forms of "life-work" falling outside the parameters of formally recognized work.

Marx was not unaware of the potential of money markets. His "general formula for capital" concluded with the case of interest-bearing capital-a mode of circulation in which the intermediate stage was lost and money begot money, or "money [was] worth more money, value [was] greater than itself" (Process of Production 257). While the third and final volume of Capital explored the contradictions of the sphere of circulation, Marx had already placed considerable emphasis on the productive forces and the relations of production in the first volume. The prominence of finance capital in the twenty-first century, however, can hardly be ignored, nor can the sphere of circulation that makes it so generative. Indeed, the emergence of circulation "as the cutting edge of capitalism" has radically transformed our modern market economy, decoupling capital from sites of production and reorganizing state functions (LiPuma and Lee 9).

While the "cultures of circulation" Lee and LiPuma describe signal the amplification of circuits of finance capital, and while such circuits and their velocity may distinguish the contemporary conjuncture (by the velocity of circulation and the integration of markets), the apparent absence of "real production" marks a mystification rather than the actual dissolution of the commodity-namely, abstracted labor value-in the M-C-M $\mathrm{M}^{\prime}$ formulation. Still, labor's apparent disappearance-an ongoing crisis of capital dating back to the period before South Africa's transition-is paralleled by the lived experience of absent and inadequate wage work and the concomitant growing extremes of wealth and poverty. In a world peculiarly defined by promise and powerlessness, poor people survive in part because of a certain optimal pragmatism-in making do, in casting wide for ways to make ends meet through informal work, borrowing, and self-imposed austerity. These are all the stuff of "marginal gains."

In some formal sense, finance capital tends to dissolve $\mathrm{M}-\mathrm{C}-\mathrm{M}^{\prime}$ into $\mathrm{M}-\mathrm{M}^{\prime}$. It is striking then that in two distinct sectors of the economy-financial and informal-wage work is more or less dissolute. As fewer and fewer workers-one percent of the workforce-are 
required to drive the culture of circulation, unemployment has given rise to an everexpanding informal sector, a manifest expression of a crisis of redundancy. This crisis masks a more permanent condition, in which a mechanism that produces "superfluous" populations is constituted by the very superfluity it generates, rendering superfluity necessary to the system as a whole (Makhulu, "Question").

I have tried to argue that South Africa's history of work, beginning in the nineteenth century, is critical to how we understand the ongoing challenges of the postwage economy in South Africa. This is a matter not only of asserting the "right" political-economic theory ${ }^{22}$-distinguishing between schools of thought that have long framed South African debates about apartheid labor, the reserve system, race and class, and uneven and combined development-but also of elaborating the ways in which the privileging of work by the state in the past and the focus on the worker-citizen in contemporary South Africa inform a nostalgia for the time of apartheid work. This nostalgia is connected to a history of narrative continuity, of personal biography, of negotiating forms of life and how to reproduce them.

Just as the Occupy Movement in the United States reflects a growing recognition of the unsustainability of current conditions of inequality there, the new South African protest politics engages an array of issues that speak both to the historical conditions of the South African present and to South Africa's increasing entanglements with the world. Those entanglements make for a precarious daily life, in which mechanisms of fictitious capital formation convert or capture modes of life even as such modes constitute a form of "work on the world." South Africans daily try to reproduce and transform the conditions of their lives, however precarious, through informal home building, land invasion, battles in the courts, acts of "staying put" and occupation, and myriad other practices of the everyday-what Maurizio Lazzarato has described as the transition from "capitallabour" to "capital-life" as a way of creating and recognizing other forms of value.

\section{NOTES}

1. Makhulu, Buggenhagen, and Jackson; Roitman, Fiscal Disobedience.

2 . The last thirty years have seen wage repression in the lower ranks of the economy and enormous salary inflation in an elite class that relies for the most part on income from speculation on asset values (Harvey, Enigma 29).

3. Comaroff and Comaroff, Theory; see also Makhulu, Buggenhagen, and Jackson; Connell.

4. E.g., Standing; Harvey, Condition and Brief History; cf. Berardi; Papadopoulos, Stephenson, and Tsianos.

5. The first decade of the twenty-first century has been marked by economic growth while unemployment has been largely unaffected. Among the economically active population in South Africa, the unemployment rate in 2009 was twenty-three percent generally and closer to twenty-seven percent for black South Africans specifically (Barchiesi 5)

6. One need only consider the long-standing and vexed question of hawking (street vending) in South Africa, which was construed first as a blight on the city and then, after the democratic transition, as a source of revenue for struggling municipalities.

7. Comaroff and Comaroff, "Madman" and Dialectics.

8. What follows is largely drawn from Bond's wonderfully comprehensive account, "A Half-Century of Competing Political Economic Traditions in South Africa."

9. Migrant labor defined a relation between rural and urban areas; it also mediated the political relation between metropolitan South Africa and its peripheral reserves, which became outposts of indirect rule-incorporated less through governance than through the labor market (Mamdani).

10. Makhulu, "Search" 44; see also Arendt; Mbembe.

11. The new African National Congress government agreed to repay $\$ 25$ billion in inherited apartheid-era foreign debt. Aligning itself with the Washington Consensus's policies of fiscal discipline, deregulation, and trade liberalization, the new government went further in agreeing to tariff and trade regulations that disadvantaged South Africa while taking on $\$ 850$ million in loans from the International Monetary Fund.

12. Davis has rightly argued that one of the peculiarities of early-twenty-first-century cities is the 
disarticulation of employment from processes of urbanization even as ever-larger populations resettle there.

13. Ashman, Fine, and Newman 186.

14. Significant drops in the unemployment rate since 2003, when unemployment was almost forty percent, are difficult to assess because government statistics account only for those still looking for work ("Quarterly Labour Force Survey").

15. See also Patton; cf. Fine and Rustomjee. I am grateful for the work of the University of North Carolina, Chapel Hill, Money Group-specifically, for the group's recent focus on critical-value studies and for its efforts in thinking "conjuncturally" about the most effective and prescient analytic work that could characterize the modalities and mechanisms of capital formation in the early twenty-first century.

16. My thanks go to Carolyn Hardin for her extraordinary paper "Securities Proliferation and Value Capture in Financial Capitalism."

17. Simone; Roitman, "Politics."

18. The Convention for a Democratic South Africa met first in December 1991 and, after talks foundered, resumed in March 1993. The 1994 elections were the culmination of bilateral talks in which the National Party and the African National Congress agreed to compromises relating to constitutional guidelines for a multiparty, multiracial system.

19. The description of "roasting human flesh" refers to the brutal act of "necklacing" practiced during the struggle to end apartheid, thought to have been a practice of the Rhodesian security forces adopted by "people's courts." Several hundred such executions were documented in South Africa by the Truth and Reconciliation Commission (654-58; see also Cole 91-120).

20. Even American commentators have found themselves arguing that financialization is a consequence, not a cause, of volatility. A recent New York Times editorial has argued that inequality should be regarded as a symptom of speculation: "Extreme inequality is the hallmark of a dysfunctional economy, dominated by a financial sector that is driven as much by speculation, gouging and government backing as by productive investment-a truth that is now only beginning to reveal itself in the context of the US Occupy Wall Street Movement and which reverses prior assumptions that inequality drove speculation as the natural impulse to gamble in the face of limited opportunities for profit" ("Protestors").

21. Bryant; Gibson; Ballard, Habib, and Valodia; Oldfield and Stokke; Pithouse; Sinwell.

22. Roubini and Mihm; Stiglitz; Foster and Magdoff.

\section{Works Cited}

Abrahams, Peter. Mine Boy. 1946. Oxford: Heinemann, 1989. Print.
Amin, Samir. Unequal Development: An Essay on the Social Formations of Peripheral Capitalism. New York: Monthly Rev., 1976. Print.

Apter, Andrew. The Pan-African Nation: Oil and the Spectacle of Culture in Nigeria. Chicago: $\mathrm{U}$ of Chicago $\mathrm{P}$, 2005. Print.

Arendt, Hannah. The Origins of Totalitarianism. New York: Harvest-Harcourt, 1994. Print.

Ashman, Sam, Ben Fine, and Susan Newman. "The Crisis in South Africa: Neoliberalism, Financialization and Uneven and Combined Development." Socialist Register 47 (2011): 174-95. Print.

Bähre, Erik. "Liberation and Redistribution: Social Grants, Commercial Insurance, and Religious Riches in South Africa." Comparative Studies in Society and History 53.2 (2011): 371-92. Proquest. Web. 12 July 2012.

Ballard, Richard, Adam Habib, and Imraan Valodia, eds. Voices of Protest: Social Movements in Post-apartheid South Africa. Durban: U of KwaZulu Natal P, 2006. Print.

Barchiesi, Franco. Precarious Liberation: Workers, the State, and Contested Social Citizenship in Postapartheid South Africa. Albany: State U of New York P, 2011. Print.

Bayart, Jean-François. The State in Africa: The Politics of the Belly. London: Longman, 1993. Print.

Berardi, Franco "Bifo." The Soul at Work: From Alienation to Autonomy. Trans. Francesca Cadel and Giuseppina Mecchia. Los Angeles: Semiotext(e), 2009. Print.

Bhabha, Homi K. The Location of Culture. New York: Routledge, 1994. Print.

Bond, Patrick. Elite Transition: From Apartheid to Neoliberalism in South Africa. 2nd ed. London: Pluto, 2005. Print.

. "A Half-Century of Competing Political Economic Traditions in South Africa." Race, Class and the Developmental State. Red Location Museum, Port Elizabeth, South Africa. 16 Nov. 2010. Address.

Bonner, Philip L. "African Urbanisation on the Rand between the 1930's and 1960's: Its Social Character and Political Consequences." Journal of Southern African Studies 21.1 (1995): 115-29. Print.

Bourgouin, France. "On Being Cosmopolitan: Lifestyle and Identity of African Finance Professionals in Johannesburg." Ethnos 77.1 (2012): 50-71. Print.

Bryant, Jacob. "Towards Delivery and Dignity: Community Struggle from Kennedy Road." Journal of Asian and African Studies 43.1 (2008): 41-61. Sage Journals. Web. 12 July 2012.

Butler, Judith. Frames of War: When Is Life Grievable? New York: Verso, 2009. Print.

Chakrabarty, Dipesh. "Universalism and Belonging in the Logic of Capital." Public Culture 12.3 (2000): 653-78. Print.

Cole, Catherine M. Performing South Africa's Truth Commission: Stages of Transition. Bloomington: Indiana UP, 2010. Print. 
Comaroff, Jean, and John L. Comaroff. "Reflections on Liberalism, Policulturalism, and ID-ology: Citizenship and Difference in South Africa." Social Identities 9.4 (2003): 445-73. Print.

- Theory from the South; or, How Euro-America Is Evolving toward Africa. London: Paradigm, 2011. Print.

Comaroff, John L. "Governmentality, Materiality, Legality, Modernity: On the Colonial State in Africa." African Modernities: Entangled Meanings in Current Debate. Ed. Jan-Georg Deutsch, Peter Probst, and Heike Schmidt. Portsmouth: Heinemann, 2002. 107-34. Print.

Comaroff, John L., and Jean Comaroff. The Dialectics of Modernity on a South African Frontier. Chicago: U of Chicago P, 1997. Print. Vol. 2 of Of Revelation and Revolution. 2 vols. 1991-97.

. "The Madman and the Migrant: Work and Labor in the Historical Consciousness of a South African People." American Ethnologist 14.2 (1987): 191-209. Print.

Connell, Raewyn. Southern Theory: The Global Dynamics of Knowledge in Social Science. Malden: Polity, 2007. Print.

Cooper, Frederick. Confronting Historical Paradigms: Peasants, Labor, and the Capitalist World System in Africa and Latin America. Madison: U of Wisconsin P, 1993. Print.

- Decolonization and African Society: The Labor Question in French and British Africa. Cambridge: Cambridge UP, 1996. Print.

Davis, Mike. Planet of Slums. New York: Verso, 2006. Print.

Deleuze, Gilles, and Félix Guattari. A Thousand Plateaus: Capitalism and Schizophrenia. Trans. Brian Massumi. Minneapolis: U of Minnesota P, 1987. Print.

Denning, Michael. "Wageless Life." New Left Review 66 (2010): 79-97. Web. 12 July 2012.

Desai, Ashwin. We Are the Poors: Community Struggles in Post-apartheid South Africa. New York: Monthly Rev., 2002. Print.

Donham, Donald L. Violence in a Time of Liberation: Murder and Ethnicity at a South African Gold Mine, 1994. Photographs by Santu Mofokeng. Durham: Duke UP, 2011. Print.

Fanon, Frantz. The Wretched of the Earth. New York: Grove, 1963. Print.

Feinberg, Harvey M. “The Natives Land Act of 1913 in South Africa: Politics, Race and Segregation in the Early Twentieth Century." International Journal of African Historical Studies 26.1 (1993): 65-109. Print.

Ferguson, James. "Formalities of Poverty: Thinking about Social Assistance in Neoliberal South Africa." African Studies Review 50.2 (2007): 71-86. Print.

- Global Shadows: Africa in the Neoliberal World Order. Durham: Duke UP, 2006. Print.

Fine, Ben, and Z. Rustomjee. South Africa's Political Economy: From Minerals-Energy Complex to Industrialisation. Johannesburg: U of the Witwatersrand P, 1997. Print.
Foster, John Bellamy, and Fred Magdoff. The Great Financial Crisis: Causes and Consequences. New York: Monthly Rev., 2009. Print.

Frank, Andre Gunder. Capitalism and Underdevelopment in Latin America: Historical Studies of Chile and Bra$z i l$. New York: Monthly Rev., 1967. Print.

Freund, Bill. "Labor and Labor History in Africa: A Review of the Literature." African Studies Review 27.2 (1984): 1-58. Print.

Gelb, Steve. "Making Sense of the Crisis." Transformation 5 (1987): 33-50. Print.

Gibson, Nigel C., ed. Challenging Hegemony: Social Movements and the Quest for a New Humanism in South Africa. Trenton: New World, 2006. Print.

Gordimer, Nadine. July's People. New York: Penguin, 1982. Print.

Gramsci, Antonio. Selections from the Prison Notebooks of Antonio Gramsci. Ed. Quintin Hoare and Geoffrey Nowell Smith. New York: International, 1971. Print.

Guyer, Jane I. Marginal Gains: Monetary Transactions in Atlantic Africa. Chicago: U of Chicago P, 2004. Print.

Handler, Joel F. Social Citizenship and Workfare in the United States and Western Europe: The Paradox of Inclusion. New York: Cambridge UP, 2004. Print.

Hardin, Carolyn. "Securities Proliferation and Value Capture in Financial Capitalism.” Futures of Finance. Franklin Humanities Institute, Duke University, Durham. 24 Sept. 2011. Address.

Hart, Keith. "Informal Economy.” The Human Economy: A Citizen's Guide. Ed. Hart, Jean-Louis Laville, and Antonio David Cattani. Cambridge: Polity, 2010. 142-53. Print.

Harvey, David. A Brief History of Neoliberalism. Oxford: Oxford UP, 2005. Print.

- The Condition of Postmodernity: An Enquiry into the Origins of Cultural Change. New York: Blackwell, 1989. Print.

- The Enigma of Capital: And the Crises of Capitalism. New York: Oxford UP, 2010. Print.

- The New Imperialism. Oxford: Oxford UP, 2005. Print.

Hirsch, Alan. Season of Hope: Economic Reform under Mandela and Mbeki. Durban: U of KwaZulu Natal P, 2005. Print.

Ho, Karen. Liquidated: An Ethnography of Wall Street. Durham: Duke UP, 2009. Print.

Kruger, Loren. "Critique by Stealth: Aspiration, Consumption, and Class in Post-apartheid Television Drama." Critical Arts 24.1 (2010): 75-98. Gale. Web. 12 July 2012.

Lazzarato, Maurizio. "From Capital-Labour to CapitalLife.” Ephemera 4.3 (2004): 187-208. Ephemera. Web. 12 July 2012.

Lee, Benjamin, and Edward LiPuma. "Cultures of Circulation: The Imaginations of Modernity.” Public Culture 14.1 (2002): 191-213. Print. 
Legassick, Martin. "Race, Industrialization and Social Change in South Africa." African Affairs 75.299 (1976): 224-39. Print.

LiPuma, Edward, and Benjamin Lee. Financial Derivatives and the Globalization of Risk. Durham: Duke UP, 2004. Print.

Makhulu, Anne-Maria. “The Geography of Freedom: Cape Town in Transition." 2012. TS.

—_. "The Question of Freedom: Post-emancipation South Africa in a Neoliberal Age.” Ethnographies of Neoliberalism. Ed. Carol J. Greenhouse. Philadelphia: U of Pennsylvania P, 2010. Print.

" "The Search for Economic Sovereignty." Makhulu, Buggenhagen, and Jackson 28-47.

Makhulu, Anne-Maria, Beth Buggenhagen, and Stephen Jackson, eds. Hard Work, Hard Times: Global Volatility and African Subjectivities. Berkeley: U of California $\mathrm{P}, 2010$. Print

Mamdani, Mahmood. Citizen and Subject: Contemporary Africa and the Legacy of Late Colonialism. Princeton: Princeton UP, 1996. Print.

Marais, Hein. South Africa, Limits to Change: The Political Economy of Transition. New York: Zed, 1999. Print.

Marks, Shula, and Richard Rathbone, eds. Industrialisation and Social Change in South Africa: African Class Formation, Culture, and Consciousness, 1870-1930. New York: Longman, 1982. Print.

Marx, Karl. The Eighteenth Brumaire of Louis Bonaparte. New York: International, 1991. Print.

- The Process of Capitalist Production as a Whole. Introd. Ernest Mandel. Trans. David Fernbach. London: Penguin, 1991. Print. Vol. 3 of Capital: A Critique of Political Economy. 3 vols.

- The Process of Production of Capital. Introd. Ernest Mandel. Trans. Ben Fowkes. London: Penguin, 1990. Print. Vol. 1 of Capital: A Critique of Political Economy. 3 vols.

Mbembe, Achille. "Aesthetics of Superfluity." Public Culture 16.3 (2004): 373-405. Web. 12 July 2012.

Mbembe, Achille, and Sarah Nuttall. "Afropolis.” Introduction. Johannesburg: The Elusive Metropolis. Ed. Nuttall and Mbembe. Durham: Duke UP, 2008. 1-33. Print.

McDonald, David A. World City Syndrome: Neoliberalism and Inequality in Cape Town. New York: Routledge, 2008. Print.

Mda, Zakes. Ways of Dying. 1991. New York: Picador, 1995. Print.

Mintz, Sidney W. Sweetness and Power: The Place of Sugar in Modern History. New York: Viking, 1985. Print.

Mitlin, Diana, and David Satterthwaite, eds. Empowering Squatter Citizen: Local Government, Civil Society and Urban Poverty Reduction. London: Earthscan, 2004. Print.

Moore, Henrietta L., and Todd Sanders, eds. Magical Interpretations and Material Realities: Modernity,
Witchcraft, and the Occult in Postcolonial Africa. New York: Routledge, 2001. Print.

Moten, Fred. "Black Op.” PMLA 123.5 (2008): 1743-47. Web. 12 July 2012.

Mzobe, Sifiso. Young Blood. Cape Town: Kwela, 2010. Print. Napolitano, Joseph. "Reckoning (with) Wreckages." Johannesburg Workshop in Theory and Criticism. U of the Witwatersrand, 22 Aug. 2010. Web. 12 July 2012.

Nuttall, Sarah. "Stylizing the Self: The Y Generation in Rosebank, Johannesburg." Public Culture 16.3 (2004): 430-52. Web. 12 July 2012.

Oldfield, Sophie, and Kristian Stokke. "Polemical Politics and Local Practices of Community Organizing and Neoliberal Politics in South Africa." Contesting Neoliberalism: Urban Frontiers. Ed. Helga Leitner, Jamie Peck, and Eric Sheppard. New York: Guilford, 2007. 139-56. Print.

Papadopoulos, Dimitris, Niamh Stephenson, and Vassilis Tsianos. Escape Routes: Control and Subversion in the Twenty-First Century. London: Pluto, 2008. Print.

Paton, Alan. Cry, the Beloved Country. 1948. New York: Scribner, 2003. Print.

Patton, Paul. Deleuze and the Political. London: Routledge, 2000. Print.

Pithouse, Richard. "A Politics of the Poor: Shack Dwellers' Struggles in Durban." Journal of Asian and African Studies 43.1 (2008): 63-94. Sage Journals. Web. 12 July 2012.

Posel, Deborah. "Influx Control and Urban Labour Markets.” Apartheid's Genesis, 1935-1962. Ed. Philip Bonner, Peter Delius, and Posel. Johannesburg: Ravan, 1993. 411-30. Print.

- The Making of Apartheid, 1948-1961: Conflict and Compromise. Oxford: Clarendon, 1997. Print.

Prashad, Vijay. Keeping Up with the Dow Joneses: Debt, Prison, Workfare. Cambridge: South End, 2003. Print.

"Protestors against Wall Street." Editorial. The New York Times. New York Times, 8 Oct. 2011. Web. 11 Nov. 2011.

"Quarterly Labour Force Survey: Quarter Four." StatsOnline. Statistics South Africa, 8 Feb. 2011. Web. 12 July 2012.

Roitman, Janet L. Fiscal Disobedience: An Anthropology of Economic Regulation in Central Africa. Princeton: Princeton UP, 2005. Print.

" "The Politics of Informal Markets in Sub-Saharan Africa." Journal of Modern African Studies 28.4 (1990): 671-96. Print.

Roubini, Nouriel, and Stephen Mihm. Crisis Economics: A Crash Course in the Future of Finance. London: Penguin, 2010. Print.

Simone, AbdouMaliq. For the City Yet to Come: Changing African Life in Four Cities. Durham: Duke UP, 2004. Print.

Sinwell, Luke. "Participatory Spaces and the Alexandra Vukuzenzele Crisis Committee (AVCC): Reshaping 
Government Plans." Social Dynamics 35.2 (2009): 436-49. Print.

Standing, Guy. The Precariat: The New Dangerous Class. London: Bloomsbury Academic, 2011. Print.

Stiglitz, Joseph E. Freefall: America, Free Markets, and the Sinking of the World Economy. New York: Norton, 2010. Print.

Taussig, Michael. Shamanism, Colonialism, and the Wild Man: A Study in Terror and Healing. Chicago: U of Chicago P, 1987. Print.

Truth and Reconciliation Commission. Truth and Reconciliation Commission of South Africa Report. Vol. 7. Cape Town: Juta, 2002. Print. 7 vols. 1998-2003.

Van Onselen, Charles. New Babylon, New Nineveh: Everyday Life on the Witwatersrand, 1886-1914. 1982. Johannesburg: Ball, 2001. Print.

Wade, Jean-Philippe. "'Song of the City' and 'Mine Boy': The 'Marxist' Novels of Peter Abrahams." Research in African Literatures 21.3 (1990): 89-101. Print.
Wallerstein, Immanuel. World Systems Analysis: An Introduction. Durham: Duke UP, 2004. Print.

Weeks, Kathi. The Problem with Work: Marxism, Antiwork Politics, and Postwork Imaginaries. Durham: Duke UP, 2011. Print.

White, Hylton. "A Post-Fordist Ethnicity: Insecurity, Authority, and Identity in South Africa." Anthropological Quarterly 85.2 (2012): 397-428. Proquest. Web. 12 July 2012.

Willis, Paul. Learning to Labor: How Working Class Kids Get Working Class Jobs. 1977. New York: Columbia UP, 1981. Print.

Wolpe, Harold. "Capitalism and Cheap Labour-Power in South Africa: From Segregation to Apartheid.” Economy and Society 1.4 (1972): 425-56. Print.

. Race, Class and the Apartheid State. Paris: UNESCO, 1988. Print.

Žižek, Slavoj. "How Did Marx Invent the Symptom?” The Sublime Object of Ideology. New York: Verso, 1989. 11-53. Print. 